\title{
Synthesis, Reactivity, and Stereoselectivity of 4-Thiofuranosides
}

\author{
Jerre M. Madern, Thomas Hansen, ${ }^{\circledR}$ Erwin R. van Rijssel, Hans A.V. Kistemaker, Stefan van der Vorm, ${ }^{\circ}$ \\ Herman S. Overkleeft, Gijsbert A. van der Marel, Dmitri V. Filippov,*®i and Jeroen D.C. Codée*(i)
}

Leiden Institute of Chemistry, Leiden University, Einsteinweg 55, CC Leiden 2333, The Netherlands

\section{Supporting Information}

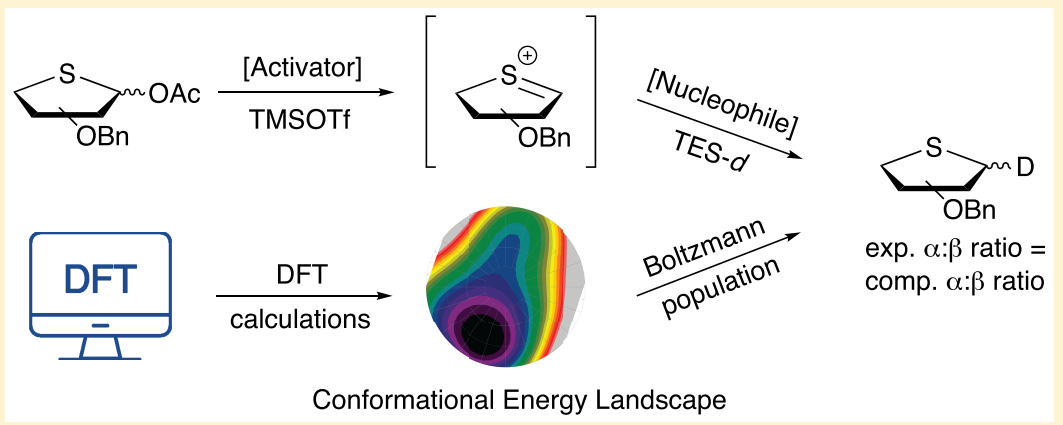

ABSTRACT: Thiosugars, sugars that have their endocyclic oxygen substituted for a sulfur atom, have been used as stable bioisosteres of naturally occurring glycans because the thiosugar glycosydic linkage is supposed to be stabilized toward chemical and enzymatic hydrolysis. We have performed an in-depth investigation into the stability and reactivity of furanosyl thiacarbenium ions, by assessing all four diastereoisomeric thiofuranosides experimentally and computationally. We show that all furanosyl thiacarbenium ions react in a 1,2-cis-selective manner with triethylsilane, reminiscent of their oxo counterparts. The computed conformational space occupied by the thiacarbenium ions is strikingly similar to that of the corresponding furanosyl oxycarbenium ions, indicating that the stereoelectronic substituent effects governing the stability of furanosyl oxocarbenium ions and thiacarbenium ions are very similar. While the thio-ribo-furanose appears to be less reactive than its oxo counterpart, the thio-ara-, lyxo-, and xylo-furanosides appear to be more reactive than their oxygen equivalents. These differences are accounted for using the conformational preference of the donors and the carbocation intermediates. The lower reactivity of the thio-ribo furanosides in (Lewis) acid-mediated reactions and the similarity of the thia- and oxocarbenium ions make thio-ribofuranosides excellent stabilized analogues of the naturally occurring ribo-furanose sugars.

\section{INTRODUCTION}

Thiosugars, 4-thiofuranosides and 5-thiopyranosides, are sugars that have their endocyclic oxygen substituted for a sulfur atom. These compounds have been found in nature, such as salacinol (Figure 1, A), an antidiabetes compound isolated from Salacia reticulata that acts as a glycosidase inhibitor. Most thiosugars reported to date are man-made, and they have been designed and generated to function as mimics of their parent $\mathrm{O}$-glycosides. As they are generally more stable toward both enzymatic ${ }^{1}$ and nonenzymatic hydrolysis, ${ }^{2}$ they may function as inhibitors for carbohydrate-processing enzymes. Indeed, the thiosugars and thio-oligosaccharides reported to date are moderately active glycosidase inhibitors, with activity in the micro to millimolar range. ${ }^{3}$ Prominent 4thiofuranosides that have been studied for their therapeutic potential owing to their increased chemical stability, ${ }^{2}$ include the 4 '-thio analogues of DNA and RNA nucleotides (Figure 1, B), and they have shown antiviral, ${ }^{4,5}$ antibiotic, ${ }^{6}$ and anticancer ${ }^{6,7}$ properties. The $4^{\prime}$-thio analogue of cADPR (Figure 1, C), which is resistant to enzymatic degradation, is a mimic of the naturally occurring cADPR, an important mediator of intracellular $\mathrm{Ca}^{2+}$ signaling. ${ }^{8}$ Recently, the 4- thioribose nicotinamide adenoside diphosphate (thio- $\mathrm{NAD}^{+}$, D) was introduced as a stabilized $\mathrm{NAD}^{+}$analogue, allowing for crystallographic studies of enzymes using this oft-used cofactor.'

To probe the stability and reactivity of thiosugars, these substrates have been subjected to various studies. In 1963, Whistler and Van Es described that methyl 5-thioxylopyranoside is hydrolyzed significantly faster than its $O$-counterpart ${ }^{10}$ and Bennet and co-workers performed an extensive suite of KIE experiments to establish that xylo- and gluco-thiacarbenium ions are more stable than the corresponding oxocarbenium ions in aqueous hydrolysis reactions. ${ }^{11,12}$ Experimental and theoretical evidence shows that sulfur atoms stabilize an adjacent carbocation better than an oxygen atom. ${ }^{13}$ However, Jagannadham et al. determined that the thermodynamically less stable, $\alpha$-oxygen-stabilized, carbocation can form more rapidly than their thermodynamically more stable $\alpha$-sulfur-stabilized counterparts, as the intrinsic kinetic barrier to the formation of the oxocarbenium ion is smaller

Received: October 1, 2018

Published: January 3, 2019 


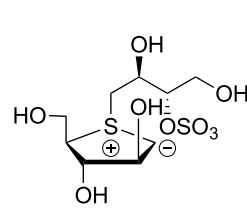

Salacinol (A)

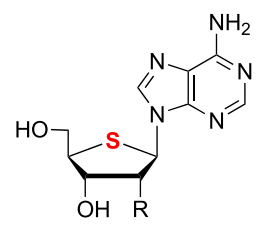

4-thio Adenosine (B)

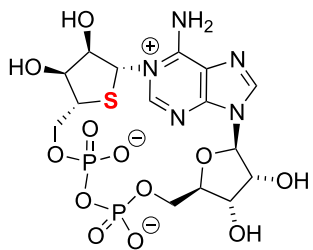

Cyclic 4'-thio ADPR (C)

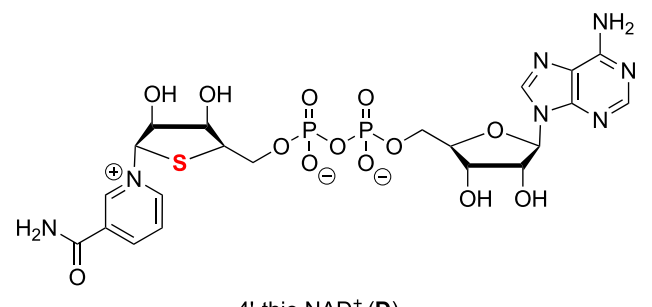

4'-thio $\mathrm{NAD}^{+}$(D)

Figure 1. Examples of biologically relevant 4-thiofuranosides.

compared to the formation of the thiacarbenium ion. ${ }^{14}$ The increased rate of hydrolysis of the thiopyranosides might be due to an additional ring strain of substituting an oxygen atom for a significantly bigger sulfur atom. In contrast, a study regarding the acid-catalyzed hydrolysis of 4-thio nucleosides has revealed a significant decrease in reactivity compared to the natural 4-oxo nucleosides, ${ }^{2}$ which is more in line with the reactivity of the acyclic benzylic substrates described by Jagannadham et al. ${ }^{14}$ To understand the stability and reactivity of furanosyl thiacarbenium ions, in support of the use of 4thiofuranosides as stabilized furanose analogues, we here describe the synthesis of the full suite of diasteroisomeric thiofuranosides (thio-ribose, thio-arabinose, thio-xylose, and thio-lyxose, Scheme 1) and a study to map structure-reactivity-

Scheme 1. Four Studied 4-Thiofuranosyl Donors

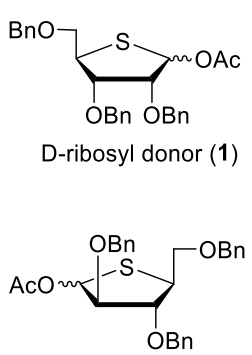

L-arabinosyl donor (3)
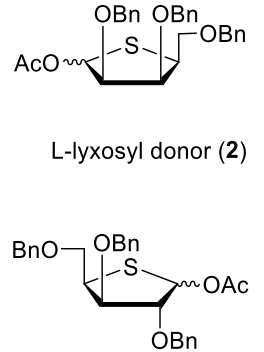

D-xylosyl donor (4) stereoselectivity relationships of these thiafuranosyl acetyl donors in Lewis-acid-mediated $\mathrm{S}_{\mathrm{N}} 1$-type substitution reactions. The putative ribosyl, arabinosyl, xylosyl, and lyxosyl thiacarbenium ion intermediates were investigated computationally following a computational method, which we recently developed to establish the stability and reactivity of fully decorated furanosyl oxocarbenium ions. ${ }^{15,16}$ In this method, which we built on the seminal work of Rhoad and coworkers, ${ }^{17}$ the relative energy of furanosyl oxocarbenium ions is determined as a function of their overall shape. It was found that the low-energy oxocarbenium ion conformers could accurately account for the stereoselectivity of addition reactions taking place on these intermediates, thereby lending strong support for their intermediacy in the studied reactions. To investigate the reactivity/stability of the related thiacarbenium ions and establish whether the stabilizing/destabilizing substituent effects that dictate the stability and reactivity of furanosyl oxocarbenium ions are operational in thiacarbenium ions, we here extend the method to five-membered ring thiacarbenium ions. It is found that these stereoelectronic effects indeed translate well to the thiacarbenium ions and the stereoselectivity of reactions of thiafuranosyl donors, in which these cations feature as product-forming intermediates can be well accounted for by the shape of the intermediate ions.

\section{RESULTS AND DISCUSSION}

The four required 4-thiofuranosyl donors ribose 1, lyxose 2, arabinose 3, and xylose 4 were synthesized following the method reported by Minakawa et al. as depicted in Scheme $2 .^{18}$ The synthesis of the 4-thio ribosyl donor 1 started from Dribose to afford, after standard protecting group manipulations, 2,3,5-tri-O-benzyl ribose 7 in $88 \%$ yield over three steps. Reduction of the lactol with sodium borohydride in methanol yielded the corresponding ribitol, of which both hydroxyl functionalities were mesylated to provide dimesylate 9. To generate the thio-ribofuranosyl donor $\mathbf{1}$, a double inversion of the C-4-mesylate was required. To this end, both mesylates in 9 were substituted by bromines in a Finkelstein-type reaction. Next, a second substitution and concomitant ring closure were effected by an $S_{N} 2$ substitution using sodium sulfide in DMF at $100{ }^{\circ} \mathrm{C}$ to give thioether 11 in $63 \%$ over three steps. These last two reactions required specific attention, as epimerization can occur on both the $\mathrm{C} 3$ and $\mathrm{C} 4$ positions, leading to the formation of a mixture of stereoisomers. (See the Supporting Information for more information.) To deliver the required acetyl donor $\mathbf{1}$, thioether $\mathbf{1 1}$ was oxidized with $m$-CPBA, to give the corresponding sulfoxide, which was transformed through a Pummerer rearrangement in donor 1 in $81 \%$ yield over two steps. Dimesylate 9 was also used for the construction of the 4-thio lyxofuranosyl donor 2. To this end, 9 was exposed to the sodium sulfide substitution/ring closure conditions to provide 4-thio L-lyxitol 13. This compound was then oxidized, to give, after a Pummerer rearrangement, the 4-thio lyxosyl donor 2. The 4-thio-L-arabinosyl and 4-thio-L-xylosyl donors 3 and 4 were synthesized using similar transformations starting from commercially available L-arabinose in similar overall yields (Scheme 2). With the synthesized 4-thio pentofuranosyl donors $(1,2,3,4)$ in hand, the glycosylation reactions were undertaken. All reactions were carried out in dry DCM using TMSOTf as an activator and triethylsilane- $d$ (TES- $d$ ) as a nucleophile. This nucleophile was used as we have previously shown that it can faithfully report on the stereoselectivity of $\mathrm{S}_{\mathrm{N}} 1$-type substitution reactions on glycofuranosyl oxocarbenium ions. ${ }^{15,16}$ Of note, the use of allyl trimethyl silane (TMSAll) as a nucleophile in combination with donor 1 provided the 1-allyl-4-thioribofuranoside with an identical selectivity.

The results of the glycosylation reactions are summarized in Table 1, alongside the results previously obtained for the $O$ furanosides for comparison. We first probed the reaction of ribo-donor $\mathbf{1}$ and found that a relatively high activation temperature was required $\left(-30{ }^{\circ} \mathrm{C}\right.$ with respect to a reaction temperature of $-78{ }^{\circ} \mathrm{C}$, for its oxo counterpart). Upon reaction with triethylsilane- $d$ the 1,2-cis addition product was formed selectively $(\alpha / \beta=91: 9)$. Next the other three donors similarly probed to deliver the results depicted in Table 1 and from these it becomes apparent that the stereoselectivities of the reactions of the 4-thiofuranosyl donors parallel those obtained 


\section{Scheme 2. Synthesis of 4-Thiofuranosyl Donors}

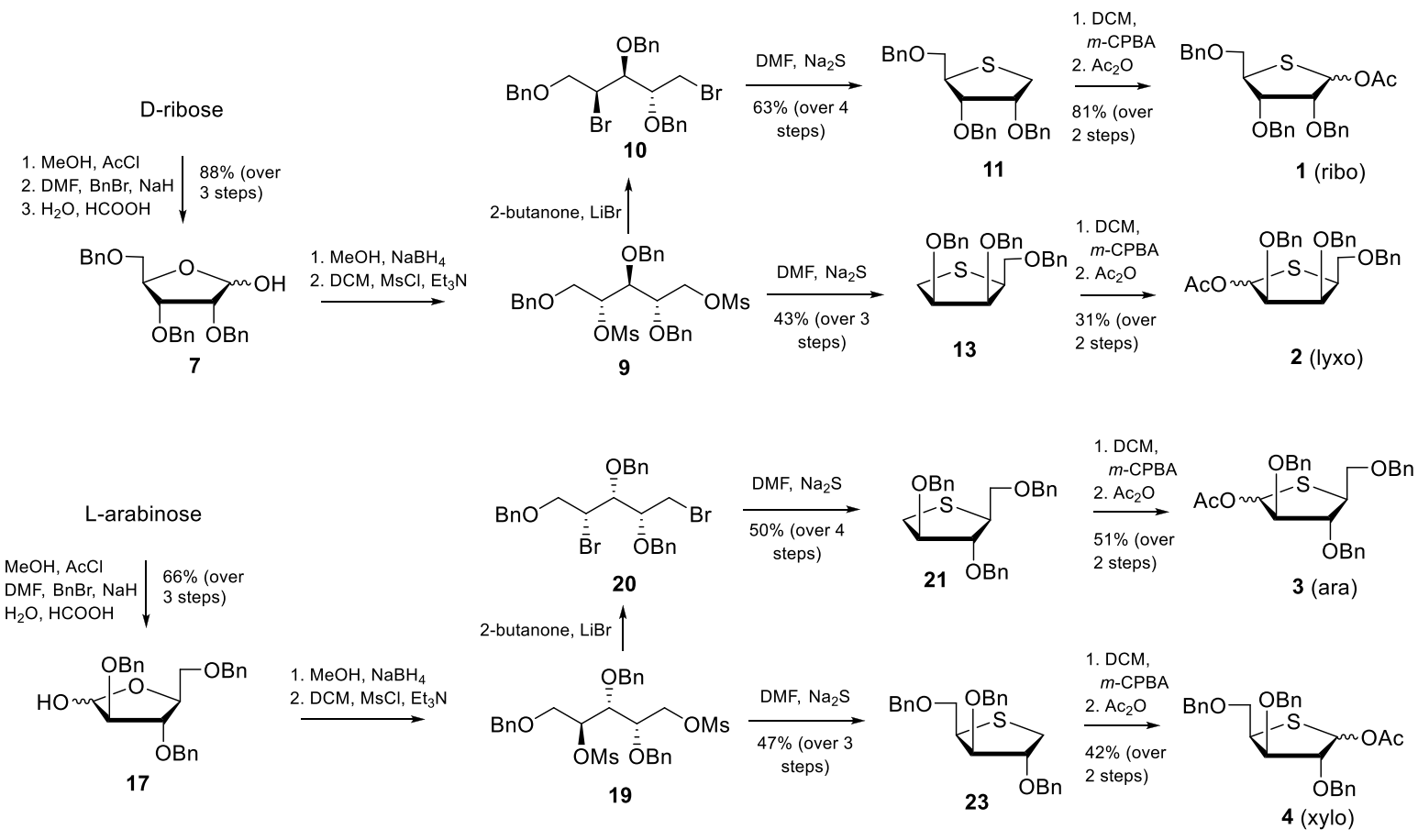

Table 1. Results of the Substitution Reaction of TES- $d$ with the 4-Oxo- and 4-Thiofuranosides

\begin{tabular}{|c|c|c|c|c|}
\hline & \multicolumn{2}{|c|}{$\mathrm{X}=\mathrm{O}$} & \multicolumn{2}{|c|}{$X=S$} \\
\hline & \multicolumn{2}{|c|}{$\alpha / \beta$ ratio $(\exp )^{a b}$} & $\alpha / \beta$ ratio (comp) & $\alpha / \beta$ ratio $(\exp )^{c b}$ \\
\hline riboside & \multicolumn{2}{|c|}{$>98: 2$} & $94: 6$ & $91: 9$ \\
\hline arabinoside & \multicolumn{2}{|c|}{$<2: 98$} & $2: 98$ & $8: 92$ \\
\hline xyloside & \multicolumn{2}{|c|}{$85: 15$} & $68: 32$ & $69: 31$ \\
\hline lyxoside & \multicolumn{2}{|c|}{$<2: 98$} & $0: 100$ & $3: 97$ \\
\hline
\end{tabular}

${ }^{a}$ Reagents and conditions: 2 equiv of TES- $d, 1.3$ equiv of TMSOTf, $-78{ }^{\circ} \mathrm{C}, 7$ days. ${ }^{b}$ The $\alpha / \beta$ ratio was established by NMR spectroscopy. ${ }^{c}$ Reagents and conditions: 2 equiv of TES- $d, 1.3$ equiv of TMSOTf, $-30{ }^{\circ} \mathrm{C}, 10$ days.

with the $O$-furanosides, but the reactions of the thiodonors are all slightly less selective. In all cases, the 1,2-cis products are formed selectively and only the 4-thioxylosyl donor 4 provides a significant amount of the trans product.

We then set out to investigate the furanosyl thiacarbenium ions using the computational approach we recently used to determine the relative energy of all furanosyl oxocarbenium ion conformers. ${ }^{15}$ To this end, we calculated the energies associated with 81 prefixed ring conformations for the thiacarbenium ions. We did so for each of the three C4-C5 rotamers, having the $\mathrm{C}-5-\mathrm{OMe}$ group in a $t g, g g$, or $g t$ position (see Figure 2B). Using Gaussian 03, employing the B3LYP hybrid functional and the $6-311 \mathrm{G}(\mathrm{d}, \mathrm{p})$ basis set, the structures of these $(3 \times 81=243)$ conformers were optimized and their relative energies calculated. The energies obtained from the DFT calculations were corrected for solvation in DCM by a polarized continuum model (PCM) and subsequently a Gibbs free energy correction was applied at the temperature of the respective experimental glycosylation. The energies of all conformations were then plotted as a polar contour plot on the pseudorotational circle (which describes the complete conformational space of a five-membered ring as a function of the phase angle $(P)$ and puckering amplitude $\left(\tau_{\mathrm{m}}\right){ }^{19}$ with isoenergetic values as the contour lines, resulting in the conformational energy landscape (CEL) map. (For more information, see the Supporting Information.) Figure 2 depicts the pseudorotational circle (A) with a set of canonical ring conformations as well as the studied C4-C5 rotamers (B). Table 2 presents the so-obtained CEL maps for both diastereoisomeric sets of furanosyl thiacarbenium ions and oxocarbenium ions. The CEL maps show that the thiacarbenium ions adopt structures that are very similar to their oxocarbenium ion counterparts and the minimal energy conformers can be found on the ${ }^{3} E-E_{3}$ axis. The presence of the 4-S ring atom does influence the amount of puckering of the five-membered ring going from an approximate puckering of $25^{\circ}$ for the oxocarbenium ions to approximately $35^{\circ}$ for the thiacarbenium ions, as a result of the larger bond length for the $\mathrm{C}-\mathrm{S}$ bonds. The maps of the thiacarbenium ions overall show a steeper energy landscape.

Looking at the individual stereoisomers, the CEL map of the ribofuranosyl thiacarbenium shows a clear minimum for the $E_{3}$ envelope. This structure (see Table 2) places all substituents in a position that allows for maximum stabilization of the thiacarbenium ion. As empirically established by Woerpel and co-workers ${ }^{20-24}$ and supported by previous computational studies, ${ }^{15,16,25-28}$ an oxocarbenium ion is best stabilized by an equatorial $\mathrm{OMe}$ substituent at $\mathrm{C} 2$ to allow for electron density donation by the axial $\mathrm{C} 2-\mathrm{H} 2$ bond, while the electron density of the ether group at $\mathrm{C} 3$ is nearest and most stabilizing to the electron-depleted anomeric center when placed axially. The same holds true for C5-OMe, which is positioned closest to the positive charge, when taking up the axial-gg-orientation in the $E_{3}$ envelope. The CEL maps reveal that the stereoelectronic "stability rules" that play a decisive role in determining the stability and reactivity of furanosyl oxocarbenium ions equally apply to thiacarbenium ions. A minor population of the ribosyl 


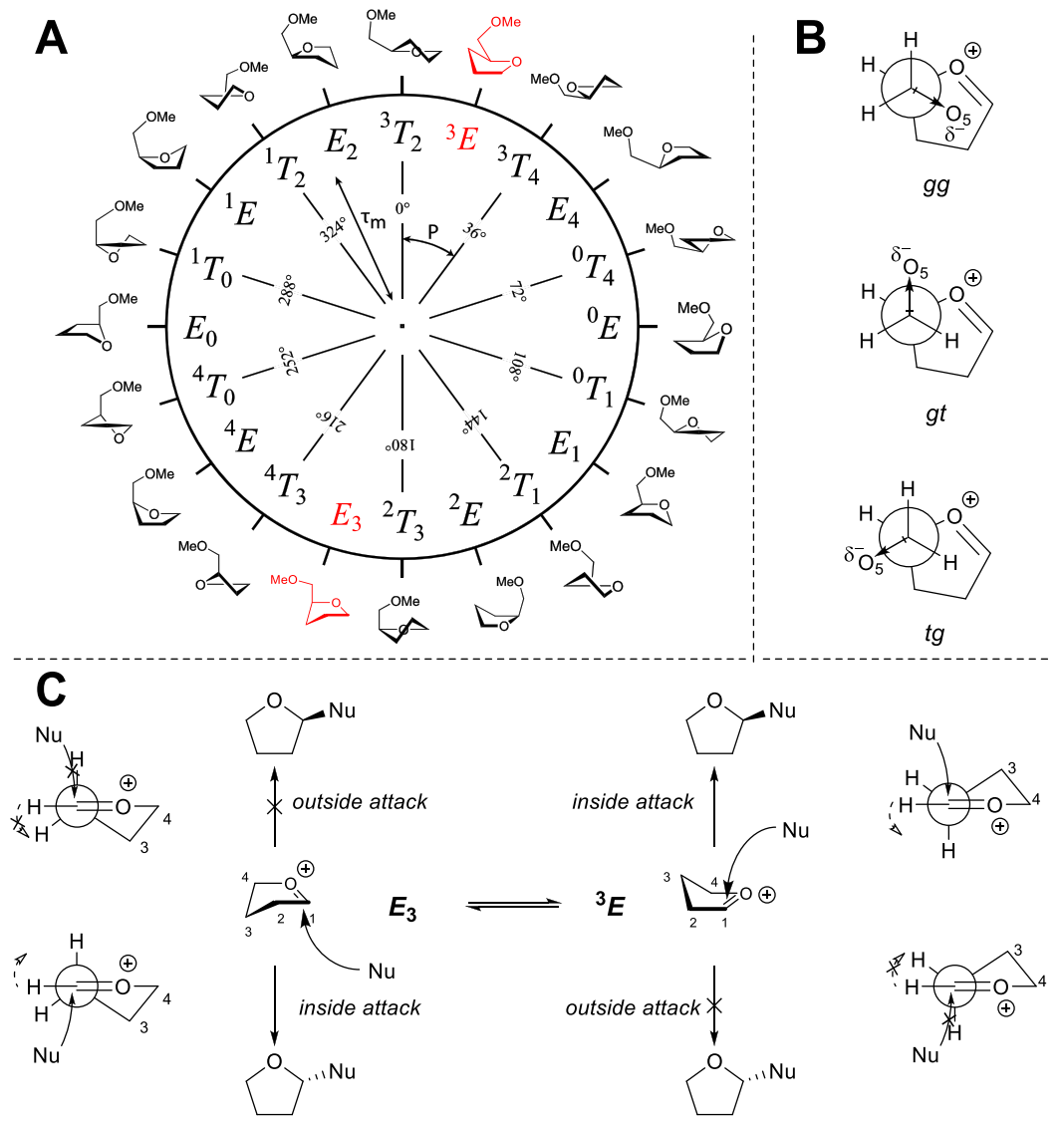

Figure 2. (A) Pseudorotational circle. (B) C4-C5 rotamers in a Newman projection. (C) Two-conformer model as advanced by Woerpel and coworkers.

thiacarbenium ion adopting a ${ }^{3} E$ conformation $\left(\Delta G_{\mathrm{DCM}}^{\mathrm{T}}=1.3\right.$ $\mathrm{kcal} / \mathrm{mol}$ ) can be found. Assuming that the $E_{3}$ thiacarbenium ion is preferentially attacked on the $\alpha$-face and the ${ }^{3} E$ structure on the opposite $\beta$-side, the Boltzmann-weighed population of both families of conformers predicts a 94:6 $\alpha / \beta$ selectivity, which closely matches the ratio obtained in the experiment (91:9).

The CEL maps of the arabinosyl and lyxosyl thiacarbenium ion show a clear preference for the ${ }^{3} E$ conformer. Nucleophilic attack on this arabinosyl ${ }^{3} E$ conformer leads to the selective formation of the $\beta$-arabinose anomer, corresponding well with the experimental findings. Similarly, the lyxosyl ${ }^{3} E$ conformer is stereoselectively attacked to provide the all-cis product. In line with the furanosyl oxocarbenium ion series, the lyxoseconfigured thiacarbenium shows the strongest preference for a single conformer, which translates into the highest stereoselectivity in the substitution reactions. For the xylofuranosyl thiacarbenium ion, two minima are found on the CEL map, matching the situation for the xylofuranosyl oxocarbenium ion. The difference in energy of the two minima is smaller in the case of the thiacarbenium ion with respect to the oxocarbenium ions and this translates into a lower stereoselectivity of thiofuranosyl donor 4 in the substitution reaction. The Boltzmann-weighed relative population of the $E_{3}$ and ${ }^{3} E$ conformers predicts a poorly selective glycosylation event, which is closely matched in the experiment. Overall, there is very good agreement between the stereoselectivity that is theoretically predicted based on the CEL maps, in combination with Woerpel's inside attack model and the stereoselectivity obtained experimentally (Table 1 ). This shows that the relative energy difference between the transition states leading to the products is relatively well approximated using the difference in ground state energy of the thiacarbenium ion conformers and that a Curtin-Hammett kinetic scenario, in which the lowest energy transition state is reached from a higher energy ground state species, plays a very minor role. The correlation between the reaction stereoselectivity and the thiacarbenium ion structure strongly indicates the thiacarbenium ions to be the product-forming reactive intermediates in these reactions.

Finally, we investigated the difference in reactivity between the $\mathrm{C} 4-\mathrm{S}$ and $\mathrm{C} 4-\mathrm{O}$ donors in a set of direct competition glycosylation experiments (Table 3). In the first set of experiments, the 4-S-ribosyl and 4-O-ribosyl ${ }^{15}$ donors, 1 and 29, were mixed and exposed to reaction conditions, in which the quantity of the activator (TMSOTf) or acceptor (TES- $d$ ) was varied to investigate whether either of the two substrates is activated more easily or if the resulting oxo- or thiacarbenium ion intermediate is more reactive toward nucleophiles (Table 3, entries 1-3). All experiments showed that the 4-thio ribofuranosyl donor reacts more slowly than its 4-oxo counterpart. For all other furanosides, the 4-thio donors reacted faster and only the 1-D products derived from these donors were formed. The striking difference in relative reactivity may be explained by the relative stability of the intermediate thia and oxo carbenium ions. In Table 2, the relative energy difference between the different diasteroisomeric CEL maps is depicted. The difference in energy between the lowest energy conformer of the individual diastereoisomers with respect to the most stable diasteroisomeric oxocarbenium 
Table 2. Conformational Energy Landscapes of the 4-Oxo Furanosyl Carbenium Ions and 4-Thio Thiacarbenium Ions

\begin{tabular}{|l|l|l|l|}
\hline & Lowest energy conformer $(\mathbf{X}=\mathbf{S})$ \\
\hline$G_{D C M}^{T}(\mathrm{kcal} / \mathrm{mol})^{\mathrm{a}}$ & & \\
\hline
\end{tabular}

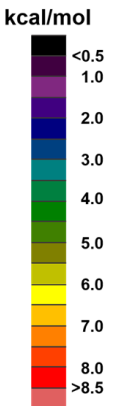

${ }^{a} \Delta G_{\mathrm{DCM}}^{\mathrm{T}}$ represents the relative energy difference between the lowest energy conformer from the given diastereoisomer with respect to the energy of the most stable conformer of the full suite of diastereoisomers.

Table 3. Results of the Substitution Reaction of TES-d with the 4-Oxo and 4-Thiofuranosides ${ }^{a}$

\begin{tabular}{|c|c|c|c|c|c|c|}
\hline entry & O donor & $S$ donor & acceptor & activator & conditions & product ratio $^{b} \mathrm{~S} / \mathrm{O}$ \\
\hline 1 & 29 ( 1 equiv) & 1 ( 1 equiv $)$ & TES- $d$ ( 2 equiv) & TMSOTf ( 2 equiv) & $-30{ }^{\circ} \mathrm{C}, 2$ days & $1: 4$ \\
\hline 2 & 29 ( 1 equiv) & 1 ( 1 equiv) & TES- $d$ ( 1 equiv) & TMSOTf ( 2 equiv) & $-30{ }^{\circ} \mathrm{C}, 2$ days & $1: 4$ \\
\hline 3 & 29 ( 1 equiv) & 1 ( 1 equiv) & TES- $d$ ( 2 equiv) & TMSOTf ( 1 equiv) & $-30{ }^{\circ} \mathrm{C}, 2$ days & $1: 3.5$ \\
\hline 4 & 31 ( 1 equiv) & 2 ( 1 equiv) & TES-d ( 1 equiv) & TMSOTf ( 2 equiv) & $-30{ }^{\circ} \mathrm{C}, 2$ days & $1: 0$ \\
\hline 5 & 33 ( 1 equiv) & 3 ( 1 equiv) & TES- $d$ ( 1 equiv) & TMSOTf ( 2 equiv) & $-30{ }^{\circ} \mathrm{C}, 2$ days & $1: 0$ \\
\hline 6 & 35 ( 1 equiv) & 4 ( 1 equiv) & TES- $d$ ( 1 equiv) & TMSOTf ( 2 equiv) & $-30{ }^{\circ} \mathrm{C}, 2$ days & $1: 0$ \\
\hline
\end{tabular}

${ }^{a}$ Competition experiments screening the reactivity of 4-oxo pentofuranosyl donors relative to 4-thio pentofuranosyl donors. ${ }^{b}$ The product ratio was established by NMR spectroscopy and isolated mass of products.

ion is $\Delta G_{\mathrm{DCM}}^{\mathrm{T}} r i b o=0 \mathrm{kcal} / \mathrm{mol} ; \Delta G_{\mathrm{DCM}}^{\mathrm{T}}$ ara $=0.1 \mathrm{kcal} / \mathrm{mol}$; $\Delta G_{\mathrm{DCM}}^{\mathrm{T}} x y l o=0.9 \mathrm{kcal} / \mathrm{mol} ; \Delta G_{\mathrm{DCM}}^{\mathrm{T}}$ lyxo $=0.2 \mathrm{kcal} / \mathrm{mol}$. Thus, in the oxo series, the ribose oxocarbenium is most stable, closely followed by the arabinose and lyxose ions, with the xylose oxocarbenium ion clearly being the least stable. The situation is rather different in the thio series. Here the order of stability is arabinose $\left(\Delta G_{\mathrm{DCM}}^{\mathrm{T}} A r a=0 \mathrm{kcal} / \mathrm{mol}\right)>$ lyxose $\left(\Delta G_{\mathrm{DCM}}^{\mathrm{T}}\right.$ lyxo $\left.=0.2 \mathrm{kcal} / \mathrm{mol}\right)>$ ribose $\left(\Delta G_{\mathrm{DCM}}^{\mathrm{T}} \mathrm{ribo}=1.4\right.$ $\mathrm{kcal} / \mathrm{mol}) \sim$ xylose $\left(\Delta G_{\mathrm{DCM}}^{\mathrm{T}} x y l o=1.4 \mathrm{kcal} / \mathrm{mol}\right)$. In this case, the ribo-thiacarbenium ion appears to be one of the least stable of the series. Overall, this data suggests that the formation of the ribo-thiacarbenium ion when compared to the formation of the corresponding oxocarbenium ion is relatively difficult, providing an explanation for the relatively low reactivity of donor 1 with respect to donor 29.

\section{CONCLUSIONS}

In conclusion, we have performed an in-depth investigation into the stability/reactivity of furanosyl thiacarbenium ions, assessing all four diastereoisomeric thiofuranosides experimentally and computationally to show that all furanosyl thiacarbenium ions react in a 1,2-cis-selective manner. There is a clear correlation to the stereoselectivity of 4-oxofuranosides, with the cationic intermediates taking up similar structures. From these results, it can be concluded that the substitution reactions follow similar reaction paths. Interest- 
ingly, differences in relative reactivity were observed for the reactivity of the 4-thio donors with respect to their oxo counterparts. While the ribo-configured 4-thio furanose is less reactive than the corresponding 4-O-furanoside, the other three diastereoisomeric 4-thio donors are more reactive than the parent 4-oxofuranosides. The relative reactivity of the ribofuranosides thus follows the reactivity difference observed for the acyclic benzylic thia/oxocarbenium ions studied by Jagannadham et al., ${ }^{14}$ while the reactivity of the arabino, xylo, and lyxo species are in line with the relative reactivity of 5-thio/ oxo pyranosides. The similar but lower reactivity of 4thioribofuranosides supports their use as stable and close mimics of the naturally occurring ribofuranosides. Finally, the results presented here show that the model for rationalizing the stereoselectivity of addition reactions to oxocarbenium ions can be extended to other nontypical glycosyl carbocations, providing further support for the model and the relevance of the reactive intermediates.

\section{EXPERIMENTAL SECTION}

General. All solvents used under anhydrous conditions were stored over $4 \AA$ molecular sieves, except for methanol, which was stored over $3 \AA$ molecular sieves. Solvents used for workup and column chromatography were of technical grade from Sigma-Aldrich and used directly. Unless stated otherwise, solvents were removed by rotary evaporation under reduced pressure at $40{ }^{\circ} \mathrm{C}$. Reactions were monitored by TLC analysis using Merck 25 DC plastikfolien 60 F254 with detection by spraying with $20 \% \mathrm{H}_{2} \mathrm{SO}_{4}$ in $\mathrm{EtOH}$, $\left(\mathrm{NH}_{4}\right)_{6} \mathrm{Mo}_{7} \mathrm{O}_{24} \cdot 4 \mathrm{H}_{2} \mathrm{O}(25 \mathrm{~g} / \mathrm{L})$, and $\left(\mathrm{NH}_{4}\right)_{4} \mathrm{Ce}\left(\mathrm{SO}_{4}\right)_{4} \cdot 2 \mathrm{H}_{2} \mathrm{O}(10$ $\mathrm{g} / \mathrm{L})$ in $10 \%$ sulfuric acid or by spraying with a solution of ninhydrin $(3 \mathrm{~g} / \mathrm{L})$ in $\mathrm{EtOH} / \mathrm{AcOH}(20: 1 \mathrm{v} / \mathrm{v})$, followed by charring at approximately $150{ }^{\circ} \mathrm{C}$. Column chromatography was performed on Fluka silica gel $(0.04-0.063 \mathrm{~mm})$ or by automation using a Biotage Isolera Spektra Four machine. For LC-MS analysis, a JASCO HPLC system (detection simultaneously at 214 and $254 \mathrm{~nm}$ ) equipped with an analytical C18 column $(4.6 \mathrm{~mm} \mathrm{D} \times 50 \mathrm{~mm} \mathrm{~L}, 3 \mu$ particle size $)$ in combination with buffers $\mathrm{A}\left(\mathrm{H}_{2} \mathrm{O}\right), \mathrm{B}(\mathrm{MeCN})$, and $\mathrm{C}(0.5 \%$ aq TFA) and coupled to a PE/SCIEX API 165 single quadruple mass spectrometer (PerkinElmer) was used, unless stated otherwise. Alternatively, a Thermo Finnigan LCQ Advantage MAX ion-trap mass spectrometer with an electrospray ion source coupled to a Surveyor HPLC system (Thermo Finnegan) was used with the same analytical column. High-resolution mass spectra were recorded by direct injection ( $2 \mu \mathrm{L}$ of a $2 \mu \mathrm{M}$ solution in water/acetonitrile; 50:50; $\mathrm{v} / \mathrm{v}$ and $0.1 \%$ formic acid) on a mass spectrometer (Thermo Finnigan LTQ Orbitrap) equipped with an electrospray ion source in positive mode (source voltage $3.5 \mathrm{kV}$, sheath gas flow 10 , capillary temperature $250{ }^{\circ} \mathrm{C}$ ) with a resolution $(R)=60000$ at $\mathrm{m} / \mathrm{z} 400$ (mass range $m / z=1502000)$ and dioctylpthalate $(\mathrm{m} / z=391.2842)$ as a "lock mass". The high-resolution mass spectrometer was calibrated prior to measurements with a calibration mixture (Thermo Finnigan). ${ }^{1} \mathrm{H}$ and ${ }^{13} \mathrm{C}$ NMR spectra were measured on a Bruker AV $400(400 \mathrm{MHz})$ or a Bruker DMX $600(600 \mathrm{MHz})$, and all individual signals were assigned using $2 \mathrm{D}$ NMR spectroscopy. Chemical shifts are given in $\mathrm{ppm}(\delta)$ relative to TMS $(0 \mathrm{ppm})$, and coupling constants $(J)$ are given in hertz $(\mathrm{Hz})$. Optical rotations were measured in $\mathrm{CHCl}_{3}$ or methanol at a concentration of $10 \mathrm{mg} / \mathrm{mL}$ at $25{ }^{\circ} \mathrm{C}$. Stereoisomers were, when possible, separated by silica gel column chromatography for analytical purposes. (5).

Synthesis and Characterization. Methyl $\alpha, \beta$-D-Ribofuranoside

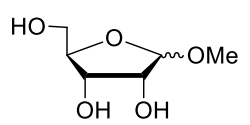

D-Ribose $(15.0 \mathrm{~g}, 100 \mathrm{mmol})$ was dissolved in methanol $(250 \mathrm{~mL})$. The solution was cooled to $0{ }^{\circ} \mathrm{C}$, and sulfuric acid $(0.27 \mathrm{~mL}, 5 \mathrm{mmol})$ was slowly added. The reaction mixture was stirred for $24 \mathrm{~h}$ at $4{ }^{\circ} \mathrm{C}$.
The reaction was quenched upon the addition of sodium bicarbonate. The reaction mixture was filtered, concentrated in vacuo, and used in the next step without further purification. $R_{f}=0.25\left(\mathrm{CHCl}_{3} / \mathrm{EtOAc} /\right.$ $\mathrm{MeOH}, 63: 25: 12$ ).

Methyl 2,3,5-Tri-O-benzyl- $\alpha, \beta$-D-ribofuranoside (6).<smiles>CO[C@H]1OC(COc2ccccc2)C(Br)OC1c1ccccc1</smiles>

Crude $5(100 \mathrm{mmol})$ was dissolved in DMF $(400 \mathrm{~mL})$. The mixture was cooled to $0{ }^{\circ} \mathrm{C}$, and sodium hydride $(350 \mathrm{mmol}, 8.40 \mathrm{~g}$, $60 \%$ in mineral oil) was slowly added. After hydrogen gas formation stopped, benzyl bromide ( $350 \mathrm{mmol}, 41.6 \mathrm{~mL}$ ) was slowly added, and the reaction mixture was stirred at room temperature for $5 \mathrm{~h}$. The reaction was quenched by the addition of ice. The reaction mixture was diluted with EtOAc and washed with water and brine. The organic layer was dried $\left(\mathrm{MgSO}_{4}\right)$, concentrated in vacuo, and used in the next step without further purification. $R_{f}=0.35$ (EtOAc/pentane, 5:95).

\section{2,3,5-Tri-O-benzyl- $\alpha, \beta$-D-ribose (7).}

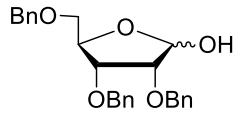

Crude $6(100 \mathrm{mmol})$ was dissolved in formic acid $(800 \mathrm{~mL})$ and water $(200 \mathrm{~mL})$, and the mixture was stirred at $60{ }^{\circ} \mathrm{C}$ for $18 \mathrm{~h}$. The reaction mixture was diluted with diethyl ether, and the organic layer was washed with water and aq $\mathrm{NaHCO}_{3}$ (sat.), dried $\left(\mathrm{MgSO}_{4}\right)$, and concentrated in vacuo, and column chromatography (pentane/ EtOAc, 95:5 to 70:30) yielded the title compound (36.2 g, 86.2 mmol, $86 \%$ over three steps). Spectroscopic data was in agreement with literature. $^{15}$

(2S,3R,4R)-2,3,5-Tri-O-benzyl-pentane-1,4-diol (8).<smiles>OC[C@H](Cc1ccccc1)C(O)C(O)COc1ccccc1</smiles>

Compound 7 (21.5 mmol) was dissolved in methanol $(110 \mathrm{~mL})$, and sodium borohydride ( $43 \mathrm{mmol}, 1.63 \mathrm{~g}$ ) was added in small portions over a period of $30 \mathrm{~min}$ at $0{ }^{\circ} \mathrm{C}$. The reaction was then stirred for $1 \mathrm{~h}$ at room temperature, after which the solvent was removed in vacuo. The residue was dissolved in EtOAc, washed with water and brine, dried $\left(\mathrm{MgSO}_{4}\right)$, concentrated in vacuo, and used in the next step without further purification. $R_{f}=0.55$ (EtOAc/pentane, 40:60).

(2S,3S,4R)-2,3,5-Tri-O-benzyl-pentane-1,4-dimesylate (9).<smiles>COCC(COCc1ccccc1)[C@@H](Cc1ccccc1)OC</smiles>

Crude $8(21.5 \mathrm{mmol})$ was dissolved in DCM $(110 \mathrm{~mL})$, and triethylamine $(86 \mathrm{mmol}, 12.0 \mathrm{~mL})$ was added. Mesyl chloride $(64.5$ $\mathrm{mmol}, 5.0 \mathrm{~mL}$ ) was slowly added at $-20{ }^{\circ} \mathrm{C}$, and the reaction was stirred for $30 \mathrm{~min}$, after which it was quenched upon the addition of ice. The organic layer was washed with water, aq $\mathrm{NaHCO}_{3}$ (sat.), and brine, dried $\left(\mathrm{MgSO}_{4}\right)$, concentrated in vacuo, and used in the next step without further purification. $R_{f}=0.60(\mathrm{EtOAc} /$ pentane, 30:70).

(2R,3S,4S)-2,3,5-O-Tribenzyl-1,4-dibromopentane (10).<smiles>BrCC(Br)C(Br)C(Br)COc1ccccc1</smiles>

Crude 9 (38.4 mmol), coevaporated with toluene to remove traces of water, was dissolved in dry 2-butanone $(130 \mathrm{~mL})$. Lithium bromide $(384 \mathrm{mmol}, 33.4 \mathrm{~g}$ ) was added, and the reaction was refluxed for $16 \mathrm{~h}$. The reaction mixture was diluted with EtOAc and washed with water, aq $\mathrm{NaHCO}_{3}$ (sat.), and brine. The organic layer was dried $\left(\mathrm{MgSO}_{4}\right)$, concentrated in vacuo, and used in the next step without further purification. $R_{f}=0.55$ (EtOAc/pentane, 5:95). 
1,4-Anhydro-2,3,5-O-tribenzyl-4-thio-D-ribitol (11).

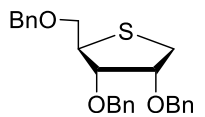

Crude 10 (38.4 mmol) and sodium sulfide nonahydrate $(46.1 \mathrm{mmol}$, $11.1 \mathrm{~g})$ were dissolved in DMF $(130 \mathrm{~mL})$. The reaction mixture was stirred at $100{ }^{\circ} \mathrm{C}$ for $30 \mathrm{~min}$. The residue was dissolved in EtOAc, washed with water and brine, dried $\left(\mathrm{MgSO}_{4}\right)$, and concentrated in vacuo. Column chromatography (pentane/EtOAc, 99:1 to 93:7) yielded the title compound $(24.0 \mathrm{mmol}, 10.1 \mathrm{~g}, 63 \%$ over 4 steps $):{ }^{1} \mathrm{H}$ NMR $\left(600 \mathrm{MHz}, \mathrm{CDCl}_{3}\right) \delta 7.59-7.13(\mathrm{~m}, 15 \mathrm{H}), 4.64-4.38(\mathrm{~m}$, $6 \mathrm{H}$ ), 3.99 (ddd, $J=6.9,5.4,3.4 \mathrm{~Hz}, 1 \mathrm{H}), 3.93(\mathrm{dd}, J=4.8,3.5 \mathrm{~Hz}$, $1 \mathrm{H}), 3.67(\mathrm{td}, J=6.6,4.6 \mathrm{~Hz}, 1 \mathrm{H}), 3.45(\mathrm{AB}, J=10.0,6.5 \mathrm{~Hz}, 2 \mathrm{H})$, $3.00(\mathrm{AB}, J=10.7,6.8 \mathrm{~Hz}, 1 \mathrm{H}), 2.84(\mathrm{AB}, J=10.7,5.4 \mathrm{~Hz}, 1 \mathrm{H})$; ${ }^{13} \mathrm{C}\left\{{ }^{1} \mathrm{H}\right\}$ NMR $\left(151 \mathrm{MHz}, \mathrm{CDCl}_{3}\right) \delta 138.0,137.9,137.9,128.3$, $128.3,128.2,127.8,127.6,127.6,127.5,127.5,80.8,79.5,72.9,71.8$, 71.7, 71.6, 47.0, 30.5; IR (neat) 3029, 2932, 2857, 1496, 1453, 1112, $1070,1027,732,694 \mathrm{~cm}^{-1}$; HRMS (ESI) $\mathrm{m} / z[\mathrm{M}+\mathrm{Na}]^{+}$calcd for $\mathrm{C}_{26} \mathrm{H}_{28} \mathrm{O}_{3} \mathrm{SNa} 443.1644$, found 443.1651; $[\alpha]_{\mathrm{D}}^{20}(c 2, \mathrm{DCM})+64.6 ; R_{f}$ $=0.35(\mathrm{EtOAc} /$ pentane, 5:95). Spectroscopic data was in agreement with literature. ${ }^{29}$

1,4-Anhydro-2,3,5-tri-O-benzyl-4-sulfoxide-D-ribitol (12).

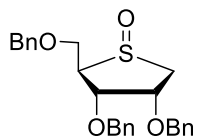

Compound 11 (15.7 mmol, 6.61 g) was dissolved in DCM $(100 \mathrm{~mL})$, and $m$-CPBA $(17.3 \mathrm{mmol}, 3.00 \mathrm{~g})$ was added at $-40^{\circ} \mathrm{C}$. The reaction mixture was stirred for $1 \mathrm{~h}$. The reaction mixture was quenched by the addition of aq $\mathrm{Na}_{2} \mathrm{~S}_{2} \mathrm{O}_{3}$ (sat.), and the organic layer was washed with aq $\mathrm{NaHCO}_{3}$ (sat.). The organic layer was dried $\left(\mathrm{MgSO}_{4}\right)$, concentrated in vacuo, and used in the next step without further purification. $R_{f}=0.05$ (EtOAc/pentane, 30:70).

1-O-Acetyl-2,3,5-tri-O-benzyl-4-thio- $\alpha, \beta$-D-ribofuranose (1).

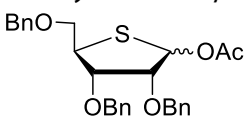

Crude $12(15.7 \mathrm{mmol})$ was dissolved in acetic anhydride $(100 \mathrm{~mL})$, and the mixture was stirred at $100{ }^{\circ} \mathrm{C}$ for $3 \mathrm{~h}$. The reaction mixture was concentrated in vacuo, and column chromatography (pentane/ EtOAc, 90:10 to 80:20) yielded the title compound (11.3 mmol, 5.4 g, $72 \%$ over two steps): ${ }^{1} \mathrm{H}$ NMR $\left(500 \mathrm{MHz}, \mathrm{CDCl}_{3}\right) \delta 7.44-7.14$ $(\mathrm{m}, 15 \mathrm{H}), 6.21(\mathrm{~d}, J=4.7 \mathrm{~Hz}, 1 \mathrm{H}), 5.97(\mathrm{~d}, J=2.0 \mathrm{~Hz}), 4.78-4.39$ (m, 6H, $\left.\mathrm{CH}_{2} \mathrm{Bn}\right), 4.11(\mathrm{dd}, J=4.1,2.2 \mathrm{~Hz}, 1 \mathrm{H}), 4.07(\mathrm{dd}, J=3.5,2.0$ $\mathrm{Hz}, 1 \mathrm{H}), 4.05-4.00(\mathrm{~m}, 1 \mathrm{H}), 3.98(\mathrm{dd}, J=8.4,3.5 \mathrm{~Hz}, 1 \mathrm{H}), 3.88-$ $3.82(\mathrm{~m}, 1 \mathrm{H}), 3.81-3.72(\mathrm{~m}, 2 \mathrm{H}), 3.59(\mathrm{AB}, J=9.8,6.9 \mathrm{~Hz}, 1 \mathrm{H})$, $3.39(\mathrm{AB}, J=10.0,5.4 \mathrm{~Hz}, 1 \mathrm{H}), 3.31(\mathrm{AB}, J=10.0,7.7 \mathrm{~Hz}, 1 \mathrm{H}), 2.12$ (s, 3H), $2.02(\mathrm{~s}, 3 \mathrm{H}) ;{ }^{13} \mathrm{C}\left\{{ }^{1} \mathrm{H}\right\}$ NMR $\left(126 \mathrm{MHz}, \mathrm{CDCl}_{3}\right) \delta 171.0$, $169.9,138.4,138.2,137.82,137.8,137.7,137.7,128.5,128.5,128.5$, $128.4,128.3,128.0,128.0,127.9,127.9,127.9,127.8,127.7,127.7$, $127.6,81.3,81.2,80.9,80.6,79.9,77.0,73.2,72.9,72.9,72.8,72.2$, 72.1, 72.0, 71.7, 71.5, 48.5, 47.9, 21.5, 21.2; IR (neat) 3064, 3030, $2939,2865,1733,1496,1454,1366,1265,1225,1102,1027,1016$, 957, 731, $695 \mathrm{~cm}^{-1}$; HRMS (ESI) $\mathrm{m} / z[\mathrm{M}+\mathrm{Na}]{ }^{+}$calcd for $\mathrm{C}_{28} \mathrm{H}_{30} \mathrm{O}_{5} \mathrm{SNa}$ 501.1706, found 501.1700; $R_{f}=0.40$ (EtOAc/pentane, 15:85).

1,4-Anhydro-2,3,5-O-tribenzyl-4-thio-L-lyxitol (13).

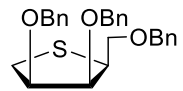

Crude 9 (12.1 mmol, $6.98 \mathrm{~g}$ ) and sodium sulfide nonahydrate (13.3 mmol, $3.18 \mathrm{~g}$ ) were dissolved in DMF $(120 \mathrm{~mL})$. The reaction mixture was stirred at $100{ }^{\circ} \mathrm{C}$ for $2 \mathrm{~h}$. The mixture was dissolved in EtOAc, washed with water and brine, dried $\left(\mathrm{MgSO}_{4}\right)$, and concentrated in vacuo. Column chromatography (pentane/EtOAc, 99:1 to 93:7) yielded the title compound ( $5.2 \mathrm{mmol}, 2.2 \mathrm{~g}$, $43 \%$ over 3 steps): ${ }^{1} \mathrm{H}$ NMR $\left(400 \mathrm{MHz}, \mathrm{CDCl}_{3}\right) \delta 7.38-7.22(\mathrm{~m}, 15 \mathrm{H}), 4.86$ $(\mathrm{d}, J=11.7 \mathrm{~Hz}, 1 \mathrm{H}), 4.68(\mathrm{~d}, J=11.8 \mathrm{~Hz}, 1 \mathrm{H}), 4.53(\mathrm{~m}, 4 \mathrm{H}), 4.20$ (dd, $J=4.1,2.8 \mathrm{~Hz}, 1 \mathrm{H}), 4.10-3.99(\mathrm{~m}, 1 \mathrm{H}), 3.90(\mathrm{dd}, J=8.4,7.0$ $\mathrm{Hz}, 1 \mathrm{H}), 3.64-3.50(\mathrm{~m}, 2 \mathrm{H}), 3.06(\mathrm{t}, J=9.4 \mathrm{~Hz}, 1 \mathrm{H}), 2.91(\mathrm{dd}, J=$ 9.8, 6.1 Hz, $1 \mathrm{H}) ;{ }^{13} \mathrm{C}\left\{{ }^{1} \mathrm{H}\right\}$ NMR $\left(101 \mathrm{MHz}, \mathrm{CDCl}_{3}\right) \delta 138.7,138.2$, 128.6 , 128.5, 128.4, 127.9, 127.8, 127.8, 127.7, 127.5, 83.6, 78.9, 73.7, 73.4, 72.3, 70.3, 45.8, 30.5; IR (neat) 3087, 3062, 3029, 2931, 2859, 1496, 1453, 1360, 1207, 1086, 1068, 1027, 732, $695 \mathrm{~cm}^{-1}$; HRMS (ESI) $\mathrm{m} / z[\mathrm{M}+\mathrm{Na}]+$ calcd for $\mathrm{C}_{26} \mathrm{H}_{28} \mathrm{O}_{3} \mathrm{SNa}$ 443.1644, found 443.1658; $[\alpha]_{\mathrm{D}}^{20}(c 1, \mathrm{DCM})-7.0 ; R_{f}=0.30$ (EtOAc/pentane, 5:95). Spectroscopic data was in agreement with literature. ${ }^{18}$

1,4-Anhydro-2,3,5-tri-O-benzyl-4-sulfoxide-L-lyxitol (14).

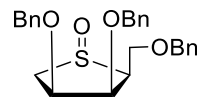

Compound 13 (4.4 mmol, $1.84 \mathrm{~g}$ ) was dissolved in DCM $(45 \mathrm{~mL})$, and $m$-CPBA $(4.8 \mathrm{mmol}, 0.83 \mathrm{~g})$ was added at $-40{ }^{\circ} \mathrm{C}$. The reaction mixture was stirred for $1 \mathrm{~h}$. The reaction mixture was quenched by the addition of aq $\mathrm{Na}_{2} \mathrm{~S}_{2} \mathrm{O}_{3}$ (sat.), and the organic layer was washed with aq $\mathrm{NaHCO}_{3}$ (sat.). The organic layer was dried $\left(\mathrm{MgSO}_{4}\right)$, concentrated in vacuo, and used in the next step without further purification. $R_{f}=0.05$ (EtOAc/pentane, 30:70).

1-O-Acetyl-2,3,5-tri-O-benzyl-4-thio- $\alpha, \beta$-L-lyxofuranose (2).

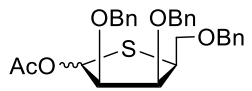

Crude 14 (4.4 mmol) was dissolved in acetic anhydride $(30 \mathrm{~mL})$, and the mixture was stirred at $100{ }^{\circ} \mathrm{C}$ for $5 \mathrm{~h}$. The reaction mixture was concentrated in vacuo, and column chromatography (pentane/ EtOAc, 90:10 to 80:20) yielded the title compound (1.34 mmol, $0.64 \mathrm{~g}, 31 \%$ over two steps): ${ }^{1} \mathrm{H}$ NMR $\left(400 \mathrm{MHz}, \mathrm{CDCl}_{3}\right) \delta 7.45-$ $7.24(\mathrm{~m}, 15 \mathrm{H}), 6.01(\mathrm{~d}, J=3.7 \mathrm{~Hz}, 1 \mathrm{H}), 4.73-4.45(\mathrm{~m}, 6 \mathrm{H}), 4.31-$ $4.28(\mathrm{~m}, 1 \mathrm{H}), 4.27-4.21(\mathrm{~m}, 1 \mathrm{H}), 4.10(\mathrm{t}, J=3.5 \mathrm{~Hz}, 1 \mathrm{H}), 4.00-$ $3.91(\mathrm{~m}, 3 \mathrm{H}), 3.78(\mathrm{dt}, J=7.9,5.6 \mathrm{~Hz}, 1 \mathrm{H}), 3.69(\mathrm{dd}, J=9.2,7.9 \mathrm{~Hz}$, $1 \mathrm{H}), 3.62-3.47(\mathrm{~m}, 2 \mathrm{H}), 2.09(\mathrm{~s}, 3 \mathrm{H}), 2.04(\mathrm{~s}, 3 \mathrm{H}) ;{ }^{13} \mathrm{C}\left\{{ }^{1} \mathrm{H}\right\} \mathrm{NMR}$ $\left(101 \mathrm{MHz}, \mathrm{CDCl}_{3}\right) \delta 138.3,138.1,137.8,128.7,128.5,128.5,128.5$, $128.3,128.1,127.9,127.9,127.8,127.8,127.7,127.6,127.5,84.5$, 84.2, 80.7, 79.5, 78.6, 76.0, 73.6, 73.5, 73.4, 72.7, 72.5, 71.2, 69.7, 46.5, 46.3, 21.5, 21.2; IR (neat) 3078, 3064, 3030, 2923, 2864, 1735, 1496, 1453, 1366, 1309, 1224, 1094, 1061, 1016, 957, 910, 733, 695 $\mathrm{cm}^{-1}$; HRMS (ESI) $\mathrm{m} / z[\mathrm{M}+\mathrm{Na}]^{+}$calcd for $\mathrm{C}_{28} \mathrm{H}_{30} \mathrm{O}_{5} \mathrm{SNa}$ 501.1706, found 501.1714; $R_{f}=0.45$ (EtOAc/pentane, 15:85).

Methyl $\alpha, \beta$-L-Aarabinofuranoside (15).

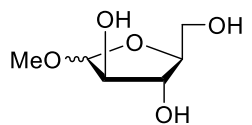

L-Arabinose ( $100 \mathrm{mmol}, 15.0 \mathrm{~g})$ was dissolved in methanol $(250 \mathrm{~mL})$. The solution was cooled to $0{ }^{\circ} \mathrm{C}$, and sulfuric acid $(5 \mathrm{mmol}, 0.27 \mathrm{~mL})$ was slowly added. The reaction mixture was stirred for 4 nights at room temperature. The reaction was quenched upon the addition of sodium bicarbonate. The reaction mixture was filtered, concentrated in vacuo, and used in the next step without further purification. $R_{f}=$ $0.30\left(\mathrm{CHCl}_{3} / \mathrm{EtOAc} / \mathrm{MeOH}, 63: 25: 12\right)$.

Methyl 2,3,5-Tri-O-benzyl- $\alpha, \beta$-L-arabinofuranoside (16).

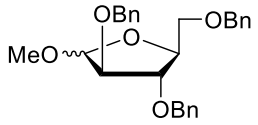

Crude 15 (100 mmol) was dissolved in DMF $(350 \mathrm{~mL})$, and the mixture was cooled to $0{ }^{\circ} \mathrm{C}$. Sodium hydride $(350 \mathrm{mmol}, 14.0 \mathrm{~g}, 60 \%$ in mineral oil) was slowly added. After hydrogen gas formation stopped, benzyl bromide $(350 \mathrm{mmol}, 41.6 \mathrm{~mL})$ was slowly added, and the reaction mixture was stirred at room temperature for $3 \mathrm{~h}$. The reaction was quenched by the addition of ice. The reaction mixture was diluted with diethyl ether and washed with water and brine. The organic layer was dried $\left(\mathrm{MgSO}_{4}\right)$, concentrated in vacuo, and used in the next step without further purification. $R_{f}=0.25$ (EtOAc/pentane, 5:95). 
2,3,5-Tri-O-benzyl- $\alpha, \beta$-L-arabinose (17).

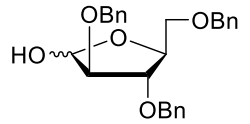

Crude $16(100 \mathrm{mmol})$ was dissolved in formic acid $(800 \mathrm{~mL})$ and water $(200 \mathrm{~mL})$, and the mixture was stirred at $60{ }^{\circ} \mathrm{C}$ for $18 \mathrm{~h}$. The reaction mixture was extracted with $\mathrm{DCM}$, and the organic layer was washed with water and aq $\mathrm{NaHCO}_{3}$ (sat.), dried $\left(\mathrm{MgSO}_{4}\right)$, and concentrated in vacuo. Column chromatography (pentane/EtOAc, 95:5 to $70: 30$ ) yielded the title compound ( $27.2 \mathrm{~g}$, $65.6 \mathrm{mmol}, 66 \%$ over three steps). Spectroscopic data was in agreement with literature. ${ }^{15}$

(2S,3S,4S)-2,3,5-Tri-O-benzyl-pentane-1,4-diol (18).<smiles>OC[C@H](Cc1ccccc1)C(O)C(O)COCc1ccccc1</smiles>

Compound 17 (64.0 mmol, $26.9 \mathrm{~g})$ was dissolved in methanol (320 $\mathrm{mL}$ ), and sodium borohydride ( $134 \mathrm{mmol}, 5.1 \mathrm{~g}$ ) was added in small portions over a period of $30 \mathrm{~min}$ at $0{ }^{\circ} \mathrm{C}$. The reaction was then stirred for $1.5 \mathrm{~h}$ at room temperature, after which the solvent was removed in vacuo. The residue was dissolved in EtOAc, washed with water and brine, dried $\left(\mathrm{MgSO}_{4}\right)$, concentrated in vacuo, and used in the next step without further purification. $R_{f}=0.45$ (EtOAc/pentane, 40:60).

(2S,3R,4S)-2,3,5-Tri-O-benzyl-pentane-1,4-dimesylate (19).<smiles>COC[C@H](Cc1ccccc1)[C@@H](OC)[C@H](COCc1ccccc1)OC</smiles>

Crude 18 (64 mmol) was dissolved in DCM (300 mL), and triethylamine $(256 \mathrm{mmol}, 36.0 \mathrm{~mL})$ was added. Mesyl chloride $(192$ mmol, $15.0 \mathrm{~mL}$ ) was slowly added at $-20{ }^{\circ} \mathrm{C}$, and the reaction was stirred for $30 \mathrm{~min}$, after which it was quenched upon the addition of ice. The organic layer was washed with water, aq $\mathrm{NaHCO}_{3}$ (sat.), and brine, dried $\left(\mathrm{MgSO}_{4}\right)$, concentrated in vacuo, and used in the next step without further purification. $R_{f}=0.45$ (EtOAc/pentane, 30:70).

(2R,3R,4R)-2,3,5-O-Tribenzyl-1,4-dibromopentane (20).

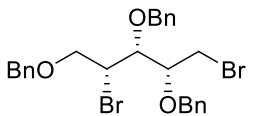

Crude $19(27.2 \mathrm{mmol})$, coevaporated with toluene to remove traces of water, was dissolved in dry 2-butanone $(100 \mathrm{~mL})$. Lithium bromide $(226 \mathrm{mmol}, 19.6 \mathrm{~g})$ was added, and the reaction was refluxed for $20 \mathrm{~h}$. The reaction mixture was diluted with EtOAc and washed with water, aq $\mathrm{NaHCO}_{3}$ (sat.), and brine. The organic layer was dried $\left(\mathrm{MgSO}_{4}\right)$, concentrated in vacuo, and used in the next step without further purification. $R_{f}=0.60$ (EtOAc/pentane, 5:95).

1,4-Anhydro-2,3,5-O-tribenzyl-4-thio-L-arabitol (21).

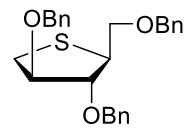

Crude $20(27.2 \mathrm{mmol})$ and sodium sulfide nonahydrate $(24.9 \mathrm{mmol}$, $6.0 \mathrm{~g}$ ) were dissolved in DMF $(220 \mathrm{~mL})$. The reaction mixture was stirred at $100{ }^{\circ} \mathrm{C}$ for $30 \mathrm{~min}$. The residue was dissolved in EtOAc, washed with water and brine, dried $\left(\mathrm{MgSO}_{4}\right)$, and concentrated in vacuo. Column chromatography (pentane/EtOAc, 99:1 to 93:7) yielded the title compound ( $13.6 \mathrm{mmol}, 5.7 \mathrm{~g}, 50 \%$ over 4 steps $):{ }^{1} \mathrm{H}$ $\operatorname{NMR}\left(400 \mathrm{MHz}, \mathrm{CDCl}_{3}\right) \delta 7.39-7.22(\mathrm{~m}, 15 \mathrm{H}), 4.61(\mathrm{~s}, 2 \mathrm{H}), 4.54-$ $4.45(\mathrm{~m}, 4 \mathrm{H}), 4.19(\mathrm{q}, J=4.6 \mathrm{~Hz}, 1 \mathrm{H}), 4.11(\mathrm{t}, J=3.7 \mathrm{~Hz}, 1 \mathrm{H}), 3.68$ $(\mathrm{dd}, J=8.9,7.6 \mathrm{~Hz}, 1 \mathrm{H}), 3.61-3.44(\mathrm{~m}, 2 \mathrm{H}), 3.07(\mathrm{dd}, J=11.3,5.1$ $\mathrm{Hz}, 1 \mathrm{H}), 2.90(\mathrm{dd}, J=11.4,4.6 \mathrm{~Hz}, 1 \mathrm{H}) ;{ }^{13} \mathrm{C}\left\{{ }^{1} \mathrm{H}\right\} \mathrm{NMR}(101 \mathrm{MHz}$, $\left.\mathrm{CDCl}_{3}\right) \delta 138.3,138.2,138.0,128.6,128.5,128.5,128.0,127.9,127.8$, 127.8, 127.7, 85.2, 73.2, 72.5, 72.0, 71.6, 49.1, 33.3; IR (neat) 3087, $3063,3029,2932,2861,1496,1362,1207,1093,1070,1028,735$, $696 \mathrm{~cm}^{-1}$; HRMS (ESI) $\mathrm{m} / z[\mathrm{M}+\mathrm{Na}]^{+}$calcd for $\mathrm{C}_{26} \mathrm{H}_{28} \mathrm{O}_{3} \mathrm{SNa}$ 443.1644, found 443.1656; $[\alpha]_{\mathrm{D}}^{20}(c \quad 0.5, \mathrm{DCM})+9.7 ; R_{f}=0.45$
(EtOAc/pentane, 5:95). Spectroscopic data was in agreement with literature. ${ }^{30}$

1,4-Anhydro-2,3,5-tri-O-benzyl-4-sulfoxide-L-arabitol (22).<smiles>O=S(O)C1CCC(OCc2ccccc2)CC1OCc1ccccc1</smiles>

Compound 21 (1.73 mmol, $0.73 \mathrm{~g})$ was dissolved in DCM $(15 \mathrm{~mL})$, and $m$-CPBA $(1.91 \mathrm{mmol}, 0.33 \mathrm{~g})$ was added at $-40{ }^{\circ} \mathrm{C}$. The reaction mixture was stirred for $2 \mathrm{~h}$. The reaction mixture was quenched by the addition of aq $\mathrm{Na}_{2} \mathrm{~S}_{2} \mathrm{O}_{3}$ (sat.), and the organic layer was washed with aq $\mathrm{NaHCO}_{3}$ (sat.). The organic layer was dried $\left(\mathrm{MgSO}_{4}\right)$, concentrated in vacuo, and used in the next step without further purification. $R_{f}=0.05$ (EtOAc/pentane, 30:70).

1-O-Acetyl-2,3,5-tri-O-benzyl-4-thio- $\alpha, \beta$-L-arabinofuranose (3).

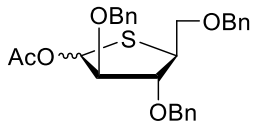

Crude $22(1.73 \mathrm{mmol})$ was dissolved in acetic anhydride $(15 \mathrm{~mL})$, and the mixture was stirred at $100{ }^{\circ} \mathrm{C}$ for $3 \mathrm{~h}$. The reaction mixture was concentrated in vacuo, and column chromatography (pentane/ EtOAc, 90:10 to 80:20) yielded the title compound (0.88 mmol, 0.42 g, $51 \%$ over two steps): ${ }^{1} \mathrm{H}$ NMR $\left(400 \mathrm{MHz}, \mathrm{CDCl}_{3}\right) \delta 7.41-7.23$ $(\mathrm{m}, 15 \mathrm{H}), 6.11(\mathrm{~d}, J=4.0 \mathrm{~Hz}, 1 \mathrm{H}), 6.02(\mathrm{~d}, J=3.0 \mathrm{~Hz}, 1 \mathrm{H}), 4.86-$ $4.50(\mathrm{~m}, 6 \mathrm{H}), 4.30(\mathrm{dd}, J=5.2,3.1 \mathrm{~Hz}, 1 \mathrm{H}), 4.27-4.12(\mathrm{~m}, 2 \mathrm{H}), 4.07$ $(\mathrm{dd}, J=6.5,5.2 \mathrm{~Hz}, 1 \mathrm{H}), 3.81(\mathrm{q}, J=6.4 \mathrm{~Hz}, 1 \mathrm{H}), 3.77-3.68(\mathrm{~m}$, 2H), 3.59-3.39 (m, 3H); ${ }^{13} \mathrm{C}\left\{{ }^{1} \mathrm{H}\right\}$ NMR (101 MHz, $\left.\mathrm{CDCl}_{3}\right) \delta$ 138.4, $138.0,137.6,128.6,128.6,128.5,128.5,128.1,128.1,128.0,128.0$, $127.9,127.9,127.8,127.8,88.9,86.1,84.7,83.9,82.1,74.8,73.6,73.3$, 73.3, 73.2, 72.9, 72.8, 72.7, 71.0, 49.5, 45.4, 21.5, 21.3; IR (neat) 3088, 3063, 3031, 2926, 2863, 1793, 1496, 1453, 1367, 1226, 1098, $1074,1017,734,695 \mathrm{~cm}^{-1}$; HRMS (ESI) $\mathrm{m} / z[\mathrm{M}+\mathrm{Na}]^{+}$calcd for $\mathrm{C}_{28} \mathrm{H}_{30} \mathrm{O}_{5} \mathrm{SNa} 501.1706$, found 501.1713; $R_{f}=0.25$ (EtOAc/pentane, 10:90). Spectroscopic data was in agreement with literature. ${ }^{31}$

1,4-Anhydro-2,3,5-O-tribenzyl-4-thio-D-xylitol (23).

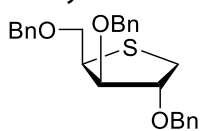

Crude 20 (10.4 mmol) and sodium sulfide nonahydrate $(10.5 \mathrm{mmol}$, $2.5 \mathrm{~g})$ were dissolved in DMF $(40 \mathrm{~mL})$. The reaction mixture was stirred at $100{ }^{\circ} \mathrm{C}$ for $4 \mathrm{~h}$. The residue was dissolved in EtOAc, washed with water and brine, dried $\left(\mathrm{MgSO}_{4}\right)$, and concentrated in vacuo. Column chromatography (pentane/EtOAc, 99:1 to 93:7) yielded the title compound (4.9 mmol, $2.0 \mathrm{~g}, 47 \%$ over 3 steps): ${ }^{1} \mathrm{H}$ NMR (400 $\left.\mathrm{MHz}, \mathrm{CDCl}_{3}\right) \delta 7.37-7.23(\mathrm{~m}, 15 \mathrm{H}), 4.61-4.45(\mathrm{~m}, 6 \mathrm{H}), 4.14(\mathrm{~m}$, $2 \mathrm{H}), 3.89-3.79(\mathrm{~m}, 2 \mathrm{H}), 3.68-3.57(\mathrm{~m}, 1 \mathrm{H}), 3.11(\mathrm{dd}, J=11.4,4.4$ $\mathrm{Hz}, 1 \mathrm{H}), 2.85$ (dd, $J=11.5,2.3 \mathrm{~Hz}, 1 \mathrm{H}) ;{ }^{13} \mathrm{C}\left\{{ }^{1} \mathrm{H}\right\}$ NMR $(101 \mathrm{MHz}$, $\left.\mathrm{CDCl}_{3}\right) \delta 138.3,138.2,138.1,128.6,128.5,128.5,127.9,127.9,127.9$, $127.8,127.7,127.7,83.1,73.4,72.8,71.4,69.4,48.1,33.2$; IR (neat) $3087,3062,3030,2935,2860,1497,1453,1392,1361,1313,1271$ 1207, 1087, 1070, 1027, 733, 695; HRMS (ESI) $m / z[\mathrm{M}+\mathrm{Na}]^{+}$ calcd for $\mathrm{C}_{26} \mathrm{H}_{28} \mathrm{O}_{3} \mathrm{SNa} 443.1644$, found 443.1657; $[\alpha]_{\mathrm{D}}^{20}(c 1, \mathrm{DCM})$ $+52.2 ; R_{f}=0.60(\mathrm{EtOAc} /$ pentane, 10:90).

1,4-Anhydro-2,3,5-tri-O-benzyl-4-sulfoxide-D-xylitol (24).

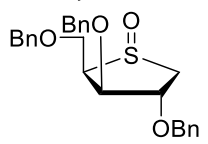

Compound 23 (4.8 mmol, $2.0 \mathrm{~g})$ was dissolved in DCM $(40 \mathrm{~mL})$, and $m$-CPBA $(5.3 \mathrm{mmol}, 0.9 \mathrm{~g})$ was added at $-40{ }^{\circ} \mathrm{C}$. The reaction mixture was stirred for $2 \mathrm{~h}$. The reaction mixture was quenched by the addition of aq $\mathrm{Na}_{2} \mathrm{~S}_{2} \mathrm{O}_{3}$ (sat.), and the organic layer was washed with aq $\mathrm{NaHCO}_{3}$ (sat.). The organic layer was dried $\left(\mathrm{MgSO}_{4}\right)$, concentrated in vacuo, and used in the next step without further purification. $R_{f}=0.05$ (EtOAc/pentane, 30:70). 
1-O-Acetyl-2,3,5-tri-O-benzyl-4-thio- $\alpha, \beta$-D-xylofuranose (4).

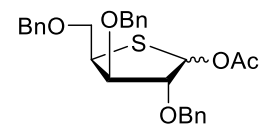

Crude $24(4.8 \mathrm{mmol})$ was dissolved in acetic anhydride $(30 \mathrm{~mL})$, and the mixture was stirred at $80{ }^{\circ} \mathrm{C}$ for $16 \mathrm{~h}$. The reaction mixture was concentrated in vacuo, and column chromatography (pentane/ EtOAc, $90: 10$ to $80: 20)$ yielded the title compound $(2.0 \mathrm{mmol}$, $0.96 \mathrm{~g}, 42 \%$ over two steps): ${ }^{1} \mathrm{H}$ NMR $\left(400 \mathrm{MHz}, \mathrm{CDCl}_{3}\right) \delta 7.37-$ $7.24(\mathrm{~m}, 15 \mathrm{H}), 6.07(\mathrm{~d}, J=4.5 \mathrm{~Hz}, 1 \mathrm{H}), 5.94(\mathrm{~d}, J=2.7 \mathrm{~Hz}, 1 \mathrm{H})$, $4.80-4.54(\mathrm{~m}, 6 \mathrm{H}), 4.39-4.25(\mathrm{~m}, 2 \mathrm{H}), 4.29-4.12(\mathrm{~m}, 2 \mathrm{H}), 3.98-$ $3.83(\mathrm{~m}, 1 \mathrm{H}), 3.79(\mathrm{dd}, J=9.6,4.7 \mathrm{~Hz}, 1 \mathrm{H}), 3.74-3.64(\mathrm{~m}, 3 \mathrm{H}), 3.53$ $(\mathrm{dd}, J=9.6,7.5 \mathrm{~Hz}, 1 \mathrm{H}), 2.09(\mathrm{~s}, 3 \mathrm{H}), 2.00(\mathrm{~s}, 3 \mathrm{H}) ;{ }^{13} \mathrm{C}\left\{{ }^{1} \mathrm{H}\right\}$ NMR $\left(101 \mathrm{MHz}, \mathrm{CDCl}_{3}\right) \delta 138.3,138.2,138.2,137.9,137.8,137.8,128.6$, $128.5,128.5,128.4,128.0,128.0,127.9,127.9,127.8,127.8,127.8$, $127.7,127.7,127.7,127.7,86.6,83.3,83.1,82.1,81.6,73.7,73.5,73.5$, 73.2, 72.7 72.5, 71.0, 69.8, 48.1, 42.1, 21.4, 21.2; IR (neat) 3063, $3031,2927,2863,1738,1496,1454,1367,1227,1093,1017,932$, $735,696 \mathrm{~cm}^{-1}$; HRMS (ESI) $\mathrm{m} / z[\mathrm{M}+\mathrm{Na}]^{+}$calcd for $\mathrm{C}_{28} \mathrm{H}_{30} \mathrm{O}_{5} \mathrm{SNa}$ 501.1706, found 501.1713; $R_{f}=0.45$ (EtOAc/pentane, 10:90). Spectroscopic data was in agreement with literature. ${ }^{32}$

1-Deutero-2,3,5-tri-O-benzyl-4-thio-D-ribitol (25).

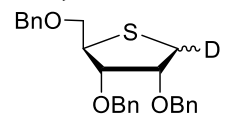

Donor $1(0.10 \mathrm{mmol}, 0.046 \mathrm{~g})$, dried by coevaporating with dry toluene $(3 \times)$, was dissolved in dry DCM $(3.22 \mathrm{~mL})$, and the mixture was stirred with freshly activated $3 \AA$ molecular sieves at room temperature for $1 \mathrm{~h}$ under argon to remove traces of water. The solution was then cooled to $-78{ }^{\circ} \mathrm{C}$, and TES- $d$ ( $\left.0.19 \mathrm{mmol}\right)$, dissolved in DCM $(0.38 \mathrm{~mL})$, was added followed by the addition of TMSOTf $(0.12 \mathrm{mmol})$, dissolved in DCM $(0.24 \mathrm{~mL})$. Next, the reaction mixture was stirred at $-30{ }^{\circ} \mathrm{C}$ for 10 days and quenched by the addition of TEA $(0.5 \mathrm{~mL})$. The reaction mixture was filtered through a path of Celite and concentrated in vacuo. Column chromatography (pentane/EtOAc, 99:1 to 93:7) yielded the title compound (0.029 g, $0.07 \mathrm{mmol}, 72 \%, \alpha / \beta=91: 9)$ : ${ }^{1} \mathrm{H}$ NMR (400 $\left.\mathrm{MHz}, \mathrm{CDCl}_{3}\right) \delta 7.37-7.23(\mathrm{~m}, 15 \mathrm{H}), 4.64-4.46(\mathrm{~m}, 6 \mathrm{H}), 4.02(\mathrm{dd}, J$ $=5.4,3.5 \mathrm{~Hz}, 1 \mathrm{H}), 3.95(\mathrm{t}, J=4.0 \mathrm{~Hz}, 1 \mathrm{H}), 3.68(\mathrm{td}, J=6.4,4.4 \mathrm{~Hz}$, $1 \mathrm{H}), 3.54-3.41(\mathrm{~m}, 2 \mathrm{H}), 3.02(\mathrm{~d}, J=6.8 \mathrm{~Hz}, 0.09 \mathrm{H}), 2.87(\mathrm{~d}, J=5.3$ $\mathrm{Hz}, 0.91 \mathrm{H}) ;{ }^{13} \mathrm{C}\left\{{ }^{1} \mathrm{H}\right\}$ NMR $\left(101 \mathrm{MHz}, \mathrm{CDCl}_{3}\right) \delta 138.2,138.2,138.1$, 128.5, 128.4, 128.1, 127.8, 127.8, 81.0, 79.7, 73.1, 72.0, 72.0, 71.9, 47.3, $30.5(\mathrm{t})$; IR (neat) 3088, 3064, 3030, 2924, 2863, 1497, 1454, $1362,1207,1107,1046,1027,763,697 \mathrm{~cm}^{-1}$; HRMS (ESI) $\mathrm{m} / z$ [M $+\mathrm{Na}]^{+}$calcd for $\mathrm{C}_{26} \mathrm{H}_{27} \mathrm{DO}_{3} \mathrm{SNa} 444.1720$, found 444.1720; $[\alpha]_{\mathrm{D}}^{20}(c$ $0.5, \mathrm{DCM})+28.2$.

1-Deutero-2,3,5-tri-O-benzyl-4-thio-L-lyxitol (26).

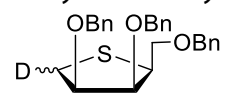

Donor $2(0.17 \mathrm{mmol}, 0.080 \mathrm{~g})$, dried by coevaporating with dry toluene $(3 \times)$, was dissolved in dry DCM $(5.3 \mathrm{~mL})$ and stirred with freshly activated $3 \AA$ molecular sieves at room temperature for $1 \mathrm{~h}$ under argon to remove traces of water. The solution was then cooled to $-78{ }^{\circ} \mathrm{C}$, and TES-d $(0.34 \mathrm{mmol})$, dissolved in DCM $(0.68 \mathrm{~mL})$, was added followed by the addition of TMSOTf $(0.22 \mathrm{mmol})$, dissolved in DCM $(0.44 \mathrm{~mL})$. Next, the reaction mixture was stirred at $-30{ }^{\circ} \mathrm{C}$ for 10 days and quenched by the addition of TEA $(0.5$ $\mathrm{mL}$ ). The reaction mixture was filtered through a path of Celite and concentrated in vacuo. Column chromatography (pentane/EtOAc, 99:1 to $93: 7)$ yielded the title compound $(0.028 \mathrm{~g}, 0.07 \mathrm{mmol}, 41 \%$, $\alpha / \beta=3: 97):{ }^{1} \mathrm{H}$ NMR $\left(400 \mathrm{MHz}, \mathrm{CDCl}_{3}\right) \delta 7.39-7.22(\mathrm{~m}, 15 \mathrm{H})$, $4.86(\mathrm{~d}, J=11.7 \mathrm{~Hz}, 1 \mathrm{H}), 4.68(\mathrm{~d}, J=11.8 \mathrm{~Hz}, 1 \mathrm{H}), 4.57(\mathrm{~s}, 2 \mathrm{H})$, $4.49(\mathrm{~s}, 2 \mathrm{H}), 4.20(\mathrm{dd}, J=4.0,2.9 \mathrm{~Hz}, 1 \mathrm{H}), 4.03(\mathrm{dd}, J=6.1,2.9 \mathrm{~Hz}$, $1 \mathrm{H}), 3.99-3.82(\mathrm{~m}, 1 \mathrm{H}), 3.63-3.50(\mathrm{~m}, 2 \mathrm{H}), 3.04(\mathrm{dd}, J=10.3,3.7$ $\mathrm{Hz}, 0.07 \mathrm{H}), 2.89(\mathrm{~d}, J=6.1 \mathrm{~Hz}, 0.93 \mathrm{H}) ;{ }^{13} \mathrm{C}\left\{{ }^{1} \mathrm{H}\right\} \mathrm{NMR}(101 \mathrm{MHz}$, $\left.\mathrm{CDCl}_{3}\right) \delta 138.8,138.3,138.2,128.6-127.5,83.6,78.9,73.7,73.4$, 72.3, 70.3, 45.8, $30.2(\mathrm{t})$; IR (neat) 3066, 3033, 2922, 2860, 1454,
$1269,1112,1027,738,698,668 \mathrm{~cm}^{-1}$; HRMS (ESI) $m / z[\mathrm{M}+\mathrm{Na}]^{+}$ calcd for $\mathrm{C}_{26} \mathrm{H}_{27} \mathrm{DO}_{3} \mathrm{SNa} 444.1720$, found 444.1720; $[\alpha]_{\mathrm{D}}^{20}(c) 1$, $\mathrm{DCM})+1.0$.

1-Deutero-2,3,5-tri-O-benzyl-4-thio-L-arabitol (27).

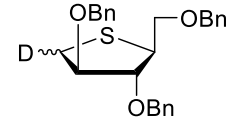

Donor $3(0.16 \mathrm{mmol}, 0.075 \mathrm{~g})$, dried by coevaporating with dry toluene $(3 \times)$, was dissolved in dry DCM $(5.3 \mathrm{~mL})$ and stirred with freshly activated $3 \AA$ molecular sieves at room temperature for $1 \mathrm{~h}$ under argon to remove traces of water. The solution was then cooled to $-78{ }^{\circ} \mathrm{C}$ and TES-d $(0.32 \mathrm{mmol})$, dissolved in DCM $(0.64 \mathrm{~mL})$, was added followed by the addition of TMSOTf $(0.21 \mathrm{mmol})$, dissolved in DCM $(0.42 \mathrm{~mL})$. Next, the reaction mixture was stirred at $-30{ }^{\circ} \mathrm{C}$ for 10 days and quenched by the addition of TEA $(0.5$ $\mathrm{mL}$ ). The reaction mixture was filtered through a path of Celite and concentrated in vacuo. Column chromatography (pentane/EtOAc, $99: 1$ to $93: 7)$ yielded the title compound $(0.046 \mathrm{~g}, 0.11 \mathrm{mmol}, 68 \%$, $\alpha / \beta=8: 92):{ }^{1} \mathrm{H}$ NMR $\left(400 \mathrm{MHz}, \mathrm{CDCl}_{3}\right) \delta 7.37-7.23(\mathrm{~m}, 15 \mathrm{H})$, $4.61(\mathrm{~s}, 2 \mathrm{H}), 4.58-4.43(\mathrm{~m}, 4 \mathrm{H}), 4.22-4.14(\mathrm{~m}, 1 \mathrm{H}), 4.11(\mathrm{t}, J=3.7$ $\mathrm{Hz}, 1 \mathrm{H}), 3.68(\mathrm{dd}, J=8.9,7.5 \mathrm{~Hz}, 1 \mathrm{H}), 3.56(\mathrm{td}, J=7.3,6.8,3.4 \mathrm{~Hz}$, $1 \mathrm{H}), 3.50(\mathrm{dd}, J=8.9,6.2 \mathrm{~Hz}, 1 \mathrm{H}), 3.06(\mathrm{~d}, J=5.1 \mathrm{~Hz}, 0.91 \mathrm{H}), 2.89$ $(\mathrm{d}, J=4.2 \mathrm{~Hz}, 0.09 \mathrm{H}) ;{ }^{13} \mathrm{C}\left\{{ }^{1} \mathrm{H}\right\} \mathrm{NMR}\left(101 \mathrm{MHz}, \mathrm{CDCl}_{3}\right) \delta 138.3$, 138.2, 138.0, 128.8-127.7, 85.1, 73.2, 72.6, 72.0, 71.6, 49.1, $33.0(\mathrm{t})$; IR (neat) 3088, 3063, 3029, 2926, 2858, 1496, 1454, 1361, 1208, 1093, 1073, 1028, 736, $697 \mathrm{~cm}^{-1}$; HRMS (ESI) $\mathrm{m} / z[\mathrm{M}+\mathrm{Na}]^{+}$ calcd for $\mathrm{C}_{26} \mathrm{H}_{27} \mathrm{DO}_{3} \mathrm{SNa} 444.1720$, found $444.1716 ;[\alpha]_{\mathrm{D}}^{20}(c 1$, DCM) +2.1 .

1-Deutero-2,3,5-tri-O-benzyl-4-thio-D-xylitol (28).

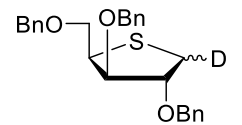

Donor $4(0.09 \mathrm{mmol}, 0.043 \mathrm{~g})$, dried by coevaporating with dry toluene $(3 \times)$, was dissolved in dry DCM $(3.0 \mathrm{~mL})$ and stirred with freshly activated $3 \AA$ molecular sieves at room temperature for $1 \mathrm{~h}$ under argon to remove traces of water. The solution was then cooled to $-78{ }^{\circ} \mathrm{C}$, and TES- $d(0.18 \mathrm{mmol})$, dissolved in DCM $(0.36 \mathrm{~mL})$, was added followed by the addition of TMSOTf $(0.12 \mathrm{mmol})$, dissolved in DCM $(0.24 \mathrm{~mL})$. Next, the reaction mixture was stirred at $-30{ }^{\circ} \mathrm{C}$ for 10 days and quenched by the addition of TEA ( 0.5 $\mathrm{mL}$ ). The reaction mixture was filtered through a path of Celite and concentrated in vacuo. Column chromatography (pentane/EtOAc, $99: 1$ to $93: 7)$ yielded the title compound $(0.023 \mathrm{~g}, 0.06 \mathrm{mmol}, 61 \%$, $\alpha / \beta=69: 31):{ }^{1} \mathrm{H}$ NMR $\left(400 \mathrm{MHz}, \mathrm{CDCl}_{3}\right) \delta 7.40-7.16(\mathrm{~m}, 15 \mathrm{H})$, $4.61-4.42(\mathrm{~m}, 6 \mathrm{H}), 4.23-4.06(\mathrm{~m}, 2 \mathrm{H}), 3.90-3.78(\mathrm{~m}, 2 \mathrm{H}), 3.62(\mathrm{q}$, $J=3.9 \mathrm{~Hz}, 1 \mathrm{H}), 3.10(\mathrm{~d}, J=4.4 \mathrm{~Hz}, 0.69 \mathrm{H}), 2.84(\mathrm{~d}, J=2.0,0.31 \mathrm{H})$; ${ }^{13} \mathrm{C}\left\{{ }^{1} \mathrm{H}\right\}$ NMR $\left(101 \mathrm{MHz}, \mathrm{CDCl}_{3}\right) \delta 138.3,138.2,138.1,128.7-$ 127.7, 83.0, 73.4, 72.8, 71.2, 69.4, 48.1, 32.9 (t); IR 3089, 3064, 3031, 2925, 2860, 1496, 1454, 1362, 1207, 1098, 1073, 1028, 735, 697 $\mathrm{cm}^{-1}$; HRMS (ESI) $\mathrm{m} / z[\mathrm{M}+\mathrm{Na}]+$ calcd for $\mathrm{C}_{26} \mathrm{H}_{27} \mathrm{DO}_{3} \mathrm{SNa}$ 444.1720, found 444.1715; $[\alpha]_{\mathrm{D}}^{20}(c 0.5, \mathrm{DCM})+21.1$.

\section{ASSOCIATED CONTENT}

\section{Supporting Information}

The Supporting Information is available free of charge on the ACS Publications website at DOI: 10.1021/acs.joc.8b02536.

Optimization of the synthetic procedures, NMR spectra, procedure for computing CEL maps, detailed description of the CEL maps, and supplementary computational data (PDF)

\section{AUTHOR INFORMATION}

\section{Corresponding Authors}

*E-mail: filippov@lic.leidenuniv.nl.

*E-mail: jcodee@chem.leidenuniv.nl. 


\section{ORCID}

Thomas Hansen: 0000-0002-6291-1569

Stefan van der Vorm: 0000-0002-4047-9373

Dmitri V. Filippov: 0000-0002-6978-7425

Jeroen D.C. Codée: 0000-0003-3531-2138

\section{Notes}

The authors declare no competing financial interest.

\section{ACKNOWLEDGMENTS}

The Netherlands Organization for Scientific Research (NWO) is acknowledged for financial support.

\section{REFERENCES}

(1) Adlercreutz, D.; Yoshimura, Y.; Mannerstedt, K.; Wakarchuk, W. W.; Bennett, E. P.; Dovichi, N. J.; Hindsgaul, O.; Palcic, M. M. Thiogalactopyranosides are Resistant to Hydrolysis by $\alpha$-Galactosidases. ChemBioChem 2012, 13 (11), 1673-1679.

(2) Elzagheid, M. I.; Oivanen, M.; Walker, R. T.; Secrist, J. A. Kinetics for the Acid-catalyzed Hydrolysis of Purine and Cytosine 2'Deoxy-4 '-Thionucleosides. Nucleosides Nucleotides 1999, 18, 181186.

(3) Mohan, S.; Pinto, B. M. Zwitterionic Glycosidase Inhibitors: Salacinol and Related Analogues. Carbohydr. Res. 2007, 342, 15511580.

(4) Bobek, M.; Bloch, A.; Whistler, R. L. Synthesis and BiologicalActivity of 4'-Thio Analogs of Antibiotic Toyocamycin. J. Med. Chem. 1972, 15, 168-171.

(5) Dyson, M. R.; Coe, P. L.; Walker, R. T. The Synthesis and Antiviral Properties of E-5-(2-Bromovinyl)-4'-Thio-2'-Deoxyuridine. J. Chem. Soc., Chem. Commun. 1991, 741-742.

(6) Secrist, J. A.; Tiwari, K. N.; Riordan, J. M.; Montgomery, J. A. Synthesis and Biological-Activity of 2'-Deoxy-4'-Thiopyrimidine Nucleosides. J. Med. Chem. 1991, 34, 2361-2366.

(7) Ototani, N.; Whistler, R. L. Preparation and Antitumor Activity of 4'-Thio Analogs of 2,2'-Anhydro-1-Beta-D-Arabinofuranosylcytosine. J. Med. Chem. 1974, 17, 535-537.

(8) Tsuzuki, T.; Sakaguchi, N.; Kudoh, T.; Takano, S.; Uehara, M.; Murayama, T.; Sakurai, T.; Hashii, M.; Higashida, H.; Weber, K.; Guse, A. H.; Kameda, T.; Hirokawa, T.; Kumaki, Y.; Potter, B. V. L.; Fukuda, H.; Arisawa, M.; Shuto, S. Design and Synthesis of Cyclic ADP-4-Thioribose as a Stable Equivalent of Cyclic ADP-Ribose, a Calcium Ion-Mobilizing Second Messenger. Angew. Chem., Int. Ed. 2013, 52, 6633-6637.

(9) Dai, Z. F.; Zhang, X. N.; Nasertorabi, F.; Cheng, Q. Q.; Pei, H.; Louie, S. G.; Stevens, R. C.; Zhang, Y. Facile Chemoenzymatic Synthesis of a Novel Stable Mimic of $\operatorname{NAD}(+)$. Chem. Sci. 2018, 9, $8337-8342$.

(10) Whistler, R. L.; Van Es, T. Solvolysis of Methyl DXylothiapyranosides and 2,3,4-Tri-O-acetyl-a-D-xylothiapyranosyl Bromide. J. Org. Chem. 1963, 28, 2303-2304.

(11) Indurugalla, D.; Bennet, A. J. A kinetic isotope effect study on the hydrolysis reactions of methyl xylopyranosides and methyl 5thioxylopyranosides: Oxygen versus sulfur stabilization of carbenium ions. J. Am. Chem. Soc. 2001, 123, 10889-10898.

(12) Johnston, B. D.; Indurugalla, D.; Pinto, B. M.; Bennet, A. J. The 5 -thioglucopyranosyl carbenium ion is a solvent-equilibrated cation. $J$. Am. Chem. Soc. 2001, 123, 12698-12699.

(13) Larson, J. R.; Epiotis, N. D. Stabilization of Charged Substrates by 1 st-Row and 2nd-Row Heteroatoms. J. Am. Chem. Soc. 1981, 103, 410-416.

(14) Jagannadham, V.; Amyes, T. L.; Richard, J. P. Kinetic and Thermodynamic Stabilities of Alpha-Oxygen-Stabilized and AlphaSulfur-Stabilized Carbocations in Solution. J. Am. Chem. Soc. 1993, 115, 8465-8466.

(15) van Rijssel, E. R.; van Delft, P.; Lodder, G.; Overkleeft, H. S.; van der Marel, G. A.; Filippov, D. V.; Codee, J. D. C. Furanosyl
Oxocarbenium Ion Stability and Stereoselectivity. Angew. Chem., Int. Ed. 2014, 53, 10381-10385.

(16) van Rijssel, E. R.; van Delft, P.; van Marle, D. V.; Bijvoets, S. M.; Lodder, G.; Overkleeft, H. S.; van der Marel, G. A.; Filippov, D. V.; Codee, J. D. C. Stereoselectivity in the Lewis Acid Mediated Reduction of Ketofuranoses. J. Org. Chem. 2015, 80, 4553-4565.

(17) Rhoad, J. S.; Cagg, B. A.; Carver, P. W. Scanning the Potential Energy Surface of Furanosyl Oxocarbenium Ions: Models for Reactive Intermediates in Glycosylation Reactions. J. Phys. Chem. A 2010, 114, 5180-5186.

(18) Minakawa, N.; Kaga, D.; Kato, Y.; Endo, K.; Tanaka, M.; Sasaki, T.; Matsuda, A. Synthesis and Structural Elucidation of 1-(3C-ethynyl-4-Thio-Beta-D-Ribofuranosyl)cytosine (4 '-ThioECyd). J. Chem. Soc. Perk. T. 1 2002, 2182-2189.

(19) Altona, C.; Sundaralingam, M. Conformational-Analysis of Sugar Ring in Nucleosides and Nucleotides - New Description Using Concept of Pseudorotation. J. Am. Chem. Soc. 1972, 94, 8205-8212.

(20) Ayala, L.; Lucero, C. G.; Romero, J. A. C.; Tabacco, S. A.; Woerpel, K. A. Stereochemistry of Nucleophilic Substitution Reactions Depending upon Substituent: Evidence for Electrostatic Stabilization of Pseudoaxial Conformers of Oxocarbenium Ions by Heteroatom Substituents. J. Am. Chem. Soc. 2003, 125, 15521-15528.

(21) Krumper, J. R.; Salamant, W. A.; Woerpel, K. A. Continuum of Mechanisms for Nucleophilic Substitutions of Cyclic Acetals. Org. Lett. 2008, 10, 4907-4910.

(22) Krumper, J. R.; Salamant, W. A.; Woerpel, K. A. Correlations Between Nucleophilicities and Selectivities in the Substitutions of Tetrahydropyran Acetals. J. Org. Chem. 2009, 74, 8039-8050.

(23) Larsen, C. H.; Ridgway, B. H.; Shaw, J. T.; Smith, D. M.; Woerpel, K. A. Stereoselective C-glycosylation Reactions of Ribose Derivatives: Electronic Effects of Five-Membered Ring Oxocarbenium Ions. J. Am. Chem. Soc. 2005, 127, 10879-10884.

(24) Larsen, C. H.; Ridgway, B. H.; Shaw, J. T.; Woerpel, K. A. A Stereoelectronic Model to Explain the Highly Stereoselective Reactions of Nucleophiles with Five-Membered-Ring Oxocarbenium Ions. J. Am. Chem. Soc. 1999, 121, 12208-12209.

(25) Hagen, B.; van der Vorm, S.; Hansen, T.; van der Marel, G. A.; Codée, J. D. C. Stereoselective Glycosylations - Additions to Oxocarbenium Ions. In Glycosylations - Synthetic Methods and Catalysts; Bennett, C., Ed.; Wiley: Weinheim, Germany, 2017.

(26) Miljkovic, M.; Yeagley, D.; Deslongchamps, P.; Dory, Y. L. Experimental and Theoretical Evidence of Through-Space Electrostatic Stabilization of the Incipient Oxocarbenium Ion by an Axially Oriented Electronegative Substituent During Glycopyranoside Acetolysis. J. Org. Chem. 1997, 62, 7597-7604.

(27) Walvoort, M. T. C.; Dinkelaar, J.; van den Bos, L. J.; Lodder, G.; Overkleeft, H. S.; Codee, J. D. C.; van der Marel, G. A. The Impact of Oxacarbenium Ion Conformers onthe Stereochemical Outcome of Glycosylations. Carbohydr. Res. 2010, 345, 1252-1263.

(28) Woods, R. J.; Andrews, C. W.; Bowen, J. P. Molecular Mechanical Investigations of the Properties of Oxocarbenium Ions.2. Application to Glycoside Hydrolysis. J. Am. Chem. Soc. 1992, 114, 859-864.

(29) Naka, T.; Minakawa, N.; Abe, H.; Kaga, D.; Matsuda, A. The Stereoselective Synthesis of 4 '-Beta-Thioribonucleosides via the Pummerer Reaction. J. Am. Chem. Soc. 2000, 122, 7233-7243.

(30) Ghavami, A.; Johnston, B. D.; Pinto, B. M. A New Class of Glycosidase Inhibitor: Synthesis of Salacinol and Its Stereoisomers. J. Org. Chem. 2001, 66, 2312-2317.

(31) Wirsching, J.; Voss, J. Thiosugars, 2 - Preparation of 2,3,5-TriO-Benzyl-4-Thio-L-Arabino-Furanosides and the Corresponding 4 '-Thionucleoside Analogues. Eur. J. Org. Chem. 1999, 1999, 691-696.

(32) Tiwari, K. N.; Messini, L.; Montgomery, J. A.; Secrist, J. A. Synthesis and Biological Activity of 4 '-Thio-1-Xylofuranosyl Purine Nucleosides. Nucleosides, Nucleotides Nucleic Acids 2005, 24, 18951906. 